\title{
LIBRARY AND INFORMATION \\ RESOURCES IN RURAL SCHOOLS OF \\ LIMPOPO PROVINCE: A SMALL STUDY
}

MAREDI SAMUEL MOJAPELO

Department of Information Science

University of South Africa

Pretoria, South Africa

mojapsm@unisa.ac.za

\section{JACQUELINE A. FOURIE}

Former lecturer, Department of Information Science

University of South Africa

Pretoria, South Africa

jackie.j.fourie@gmail.com

\section{ABSTRACT}

The purpose of this article is to report on a small study that investigated the availability of library and information resources in rural schools of Limpopo Province, South Africa. For the school curriculum to be successfully implemented, adequate library facilities, collections, staff and funds are required to support it. Data was collected by means of questionnaires directed to all teacher-librarians and principals in the high schools of the Lebopo Circuit, Capricorn District. The study found that most schools do not have functional school libraries. Converted classrooms serving as libraries are unorganised making it difficult to retrieve and access information. Some schools use staffrooms and storerooms to house library materials but learners cannot use these materials because of limited space. Unqualified teacher-librarians lack library skills and cannot guide learners to use resources. A few schools are without electricity making it impossible to operate electronic equipment. The authors recommend that schools should be provided with library-based resources managed by professionally qualified teacher-librarians to meet the needs of learners and the aims of the school curriculum.

\section{KEYWORDS}

school libraries, school library resources, rural schools, teacher-librarians, school curriculum 


\section{INTRODUCTION}

School libraries are needed to enhance learners' ability to use practical information relevant to their daily lives. Their purpose is to provide teachers and learners with library-based resources to support the curriculum. The use of library and information resources enables learners to become effective information seekers. However, only a small percentage (7.2\%) of schools in South Africa have functional school libraries. Most of these schools are located in historically white, coloured and Indian communities, whereas in disadvantaged black communities school libraries are virtually non-existent. In cases where they do exist, they are non-functional (Hart 2013:49; Machet \& Pretorius 2008:264; NEIMS 2007; Rademeyer 2007:11).

If school libraries are inadequate in urban areas, then public libraries could fulfil the function of supporting the school curriculum. However, in rural areas in developing countries there are few public libraries and learners in these areas are at a disadvantage (Okiy 2003:126; Wong 1999:142). This is particularly true of learners in remote parts of the Limpopo Province (Mahwasane 2008:2). According to the 2009/10 Draft Plan (Limpopo DSAC 2009:48), 'there is a shortage of over 100 libraries, as per quotas for the population (35 000 per library), also based on a distance radius of $15 \mathrm{~km}$ '. This means that only 10 per cent of the population in Limpopo Province has access to libraries. Although the province is large, there are currently only 43 community libraries and 20 mobile libraries that render library and information services; another 20 libraries run by non-governmental organisations also serve the population.

The resources of any organisation are people, finance, physical resources and information. The resources of the school library include its physical facilities, equipment, collections of media and information materials, funds, budgets, and staff (Fourie \& Gericke 2009:13; Smit \& Cronje 1997:355). According to the National Education Infrastructure Management System (NEIMS) (Limpopo DoBE 2007) and the Library and Information Services Transformation Charter (SA DAC \& NCLIS 2009:42), only 2.3 per cent of schools in Limpopo Province have fully-fledged school libraries with print and electronic information resources. Some schools have converted classrooms to serve as school libraries. Others have either book collections in a staff room, storeroom, passage or mobile box library, or nothing at all (Olën \& Kruger 1995:149).

Rural school libraries, where they exist anywhere in the world, are often poorly resourced, funded, stocked and managed due to budgetary constraints (Uhegbu 2001:242). Therefore, they are never self-sufficient. The necessity for resource-sharing amongst rural school libraries cannot be overemphasised (Dewe 1995:7). Furthermore, schools in rural areas are located in communities that are characterised by high levels of illiteracy, poor academic performance and a lack of established reading habits (Wijetunge 2000:144-145). Where school libraries do not exist, neither learners nor educators have access to library and information resources to develop reading skills, positive attitudes to reading and information skills (Calvert 2001:1; Magara \& Nyumba 
2004:313; Wijetunge 2000:109-110). The small number of public libraries in rural areas cannot meet these needs. Therefore, learners and teachers are obliged to rely solely on ill-equipped school libraries - if they exist. Resource allocation in rural schools is often concentrated on textbooks only without balancing the need for non-textbook reading materials which are fundamental to literacy practice, as well as consolidating reading skills and the reading habit (Wong 1999:142).

In South Africa, some rural areas do not even have electricity, a telecommunications infrastructure or tarred roads (Uhegbu 2001:242). These are some of the factors which make it extremely difficult to access library and information resources in a rural environment. For example, schools without electricity cannot access and use audiovisual and electronic equipment. Audio-visual, auditory and electronic media are essential in schools so that learners are given the opportunity to develop media and digital skills and to acquire lifelong information retrieval skills to cope with changes brought about by information and communications technologies (ICTs) (Bothma, Cosijn, Fourie \& Penzhorn 2008:12; Calvert 2001:1; Machet \& Olën 1997:77; Mutula 2004:144; Naidoo 1997:6). Electronic media, such as CD-ROMs, offer electronic access to vast databases of information ranging from encyclopaedias and newspapers to talking books, and these media could be used as a form of reading support for learners.

In January 1998, a system of outcomes-based education (better known by its acronym OBE) was implemented in South Africa. It is a learner-centred approach to teaching and learning where the emphasis is on the achievement of learning outcomes (LOs) in various learning areas. It replaced the previous system in which the teaching methods tended to be teacher-centred. OBE emphasises the use of multimedia resources to enable learners to acquire knowledge, skills, attitudes, competencies, orientations and values which are the LOs of OBE. It is regarded as a resource-based method of teaching and learning (Kruger 1998:3; Mnkeni 2007:4; Mojapelo 2008:4).

Currently, the government is in the process of implementing an entirely new education curriculum. The policy governing this new curriculum is contained in the Curriculum Assessment and Policy Statements (CAPS) (SA DoBE 2011:16-18). The emphasis is on the selection of quality learner and teacher support materials (LTSM) to implement the new curriculum. Shortly before the implementation of OBE, Kruger (1998:9-10) pointed out that:

It is unfortunately true that the people responsible for developing Curriculum $2005 \mathrm{did}$ not pay adequate, if any, attention to the school library and the role it can play in the new education system ... This oversight may easily become the Achilles heel of the new education system unless it receives the necessary attention in due course.

He suggested that learning support materials should include library books and materials, and that funds allocated for these materials should also be used to acquire library books. However, it appears as if CAPS contains no references to the use of library-based resources in the new curriculum. 
Limpopo Province is struggling to produce good Grade 12 results which could be partly due to a lack of library-based resources in schools. Although poor examination results could be ascribed to more basic problems related to the community and its social, economic and cultural environment, the library can play an important part in enhancing academic performance.

Well-equipped and functional community and school libraries should be managed by staff with the necessary qualifications. Unqualified library staff lack the skills needed to guide users in the use of library sources or to assist learners in developing information skills and the reading habit. According to the 2009/10 Draft Plan (Limpopo DSAC 2009), the existing community libraries in Limpopo are managed and run by unqualified staff. This is hampering the provision of library and information services to the communities and, therefore, to school children.

To carry out all management tasks and functions, teacher-librarians should have qualifications in both the teaching and library professions (Australian School Library and Information Association 2004:1; Mnkeni 2007:27; Saitis \& Saiti 2004:205). However, in South African public schools, specialist posts for school librarians were abolished in 1995 (Hoskins 2006:246). The only current posts are governing body posts. In other cases, the principal may judge it necessary to lighten the workload of a teacher so that the running of the library can be incorporated into the teacher's timetable. Thus, school libraries may be staffed by educators without qualifications in Library and Information Science. As there are few library posts in schools in South Africa, teacher-librarians carry out their functions on a part-time basis because they also have teaching responsibilities. This hampers their attempts to run and manage school libraries effectively and efficiently. In rural schools, the situation is even worse (Hart \& Zinn 2007:89).

\section{RESEARCH QUESTIONS}

It is clear from the above that in Limpopo Province, there are few schools in rural areas with the necessary library facilities, equipment, collections, qualified staff and funding required to support resource-based learning (SA DoE 2003:6). The purpose of the current small study was to determine to what extent library and information resources are made available in rural schools in Limpopo Province to support teaching and learning programmes as required by the school curriculum.

The research questions focused on:

- the facilities, equipment and collections owned by rural schools;

- the professional qualifications of teacher-librarians;

- the allocation of funds for schools to purchase library resources; 
- the teaching and learning programmes that require library resources to be used by teachers and learners.

\section{RESEARCH METHODOLOGY}

The research method consisted of a literature study and an empirical investigation. The aim of the study was to test the feasibility of conducting a further investigation of wider scope in future, but as the results provide answers to the research questions it should be regarded as a small study rather than a pilot study. The review of selected literature was used to study the types of library and information resources required for schools.

The questioning method of data collection was used (Van Teijlingen \& Hundley 2001:1). Structured questionnaires were personally delivered to teacher-librarians and principals at 16 rural high schools of the Lebopo Circuit in the Capricorn District, Limpopo Province. According to the Annual Survey, Update Master (Limpopo DoE 2007), the province had 1523 high schools distributed over five districts, namely, Capricorn, Mopani, Greater Sekhukhune, Vhembe and Waterberg. Capricorn District is the largest with 371 high schools distributed throughout 30 circuits. The Lebopo Circuit was chosen as representative of rural schools in Limpopo Province because all 16 high schools were situated in villages or communities headed by local indunas under Chief Molepo. At the time of the study, the researcher was a teacher-librarian at one of the 16 high schools which was being investigated. The data was collected on the availability of library and information resources, qualifications of teacher-librarians or teachers responsible for school libraries, and the funds provided to purchase library resources. The principals and teacher-librarians or teachers responsible for the school libraries were given ample time to fill in the questionnaires which were then collected for data analysis.

\section{DEFINITIONS OF RELEVANT TERMS}

\subsection{SCHOOL LIBRARY}

The school library is an educational resource centre for all learners and teachers aimed at supporting the school's teaching and learning programmes (Olën \& Kruger 1995:150; Wong 1999:142). As many schools in rural areas do not have a fully-fledged or centralised school library, the word 'school library' in the current article is used generically to denote any library provisioning facility, such as a storeroom, a staffroom or a converted classroom (SA DoBE 2012:38).

\subsection{TEACHER-LIBRARIAN}

The teacher-librarian is responsible for the day-to-day activities of the school library. $\mathrm{S} /$ he carries out the managerial functions of planning, organising, staffing, directing and controlling with the assistance of the school library committee (Olën \& Kruger 
1995:159-160; SA DoBE 2012:38). As there is a shortage of professionally qualified teacher-librarians in South Africa, the word 'teacher-librarian' is used in the study to refer to a teacher who is responsible for library resources but who may not have a professional qualification in librarianship.

\subsection{TEACHING AND LEARNING PROGRAMMES}

Although CAPS (SA DoBE 2011:9) emphasises the importance of subject content knowledge as well as skills, and uses the term 'subject' rather than 'teaching and learning area', it will take some time before the new curriculum is introduced throughout the school. In the article the term 'teaching and learning programme' is used since the study was conducted before these latest changes in educational philosophy.

Teaching and learning programmes are phase-long plans that provide frameworks for planning, organising and managing classroom practice for each phase. These include activities performed by teachers and learners to meet the requirements of the LOs as required by a resource-based curriculum. Teaching and learning programmes are, in turn, translated into year-long grades and specific work schedules which show how teaching, learning and assessment will be sequenced and paced in a particular grade (SA DoE 2003:2). A lesson plan is the next level of planning, and it is drawn directly from the work schedule. It describes in detail the teaching, learning and assessment activities that are to be implemented and managed in any given period of time in a particular grade (SA DoE 2003:2-3).

\subsection{RURAL SCHOOLS}

The term 'rural schools' in the study refers to those schools which came into existence in remote villages of Limpopo Province and were supported by their own communities and initiated by the local indunas or chiefs. They were under-resourced since the state only paid for salaries, textbooks and stationery at the time. This situation has not changed markedly as these communities are poor and lack the funds required for infrastructure development (Furlonger 2004:67; Government of Ethiopia 2005:6-7). For the purposes of the study, farm schools are not included in the concept of 'rural schools'.

\section{RESEARCH FINDINGS}

Findings obtained from responses to the questionnaires distributed to teacher-librarians and school principals in the Lebopo Circuit are presented and discussed together with other findings reported in the subject literature.

\subsection{STAFF AND THEIR QUALIFICATIONS}

Teacher-librarians were asked to indicate their teaching and Library and Information Science qualifications. These are shown in Table 1. 
Table 1: Qualifications of teacher-librarians

\begin{tabular}{|l|l|l|l|}
\hline Qualification & $\begin{array}{l}\text { Number of } \\
\text { teacher-librarians }\end{array}$ & $\begin{array}{l}\text { Total no. of } \\
\text { respondents }\end{array}$ & $\begin{array}{l}\text { Percentage } \\
\mathbf{( \% )}\end{array}$ \\
\hline Teaching diploma & 9 & 16 & 56.2 \\
\hline Teaching degree & 7 & 16 & 43.7 \\
\hline Certificate in Library and Media Studies & 2 & 16 & 12.5 \\
\hline Library and Information Science diploma & 1 & 16 & 6.2 \\
\hline
\end{tabular}

All 16 respondents had either a teaching diploma or a degree. Two teacher-librarians with certificates in Library and Media Studies run classrooms converted into school libraries. One teacher with the Diploma in Library and Information Science runs a staffroom library. The remaining teacher-librarians, including those managing centralised school libraries, do not have qualifications in school librarianship.

\subsection{FACILITIES}

Physical facilities include accommodation, furniture, equipment, computer hardware and software, and other resources which are required to house and support the library's programmes and services (Olën \& Kruger 1995:159; SA DoBE 2012:41). It goes without saying that various kinds of equipment, such as computers and photocopying machines, require electricity to operate.

\subsubsection{Accommodation}

Physical space is essential to accommodate various media formats in the collection. Respondents were asked to indicate the kind of accommodation for a resource centre or library that is available in their school. The results are shown in Figure 1.

Of all 16 high schools, only two schools have centralised school libraries. Eleven (69\%) schools have converted a classroom into a school library. The researcher observed that these converted classrooms are not library and information centres in the true sense of the word. Their collections are disorganised and unsystematic, with no catalogues to facilitate access to information or the retrieval of information sources. The remaining three (19\%) schools indicated that they have either a staffroom or storeroom that serves as an alternative type of library facility housing information sources. 


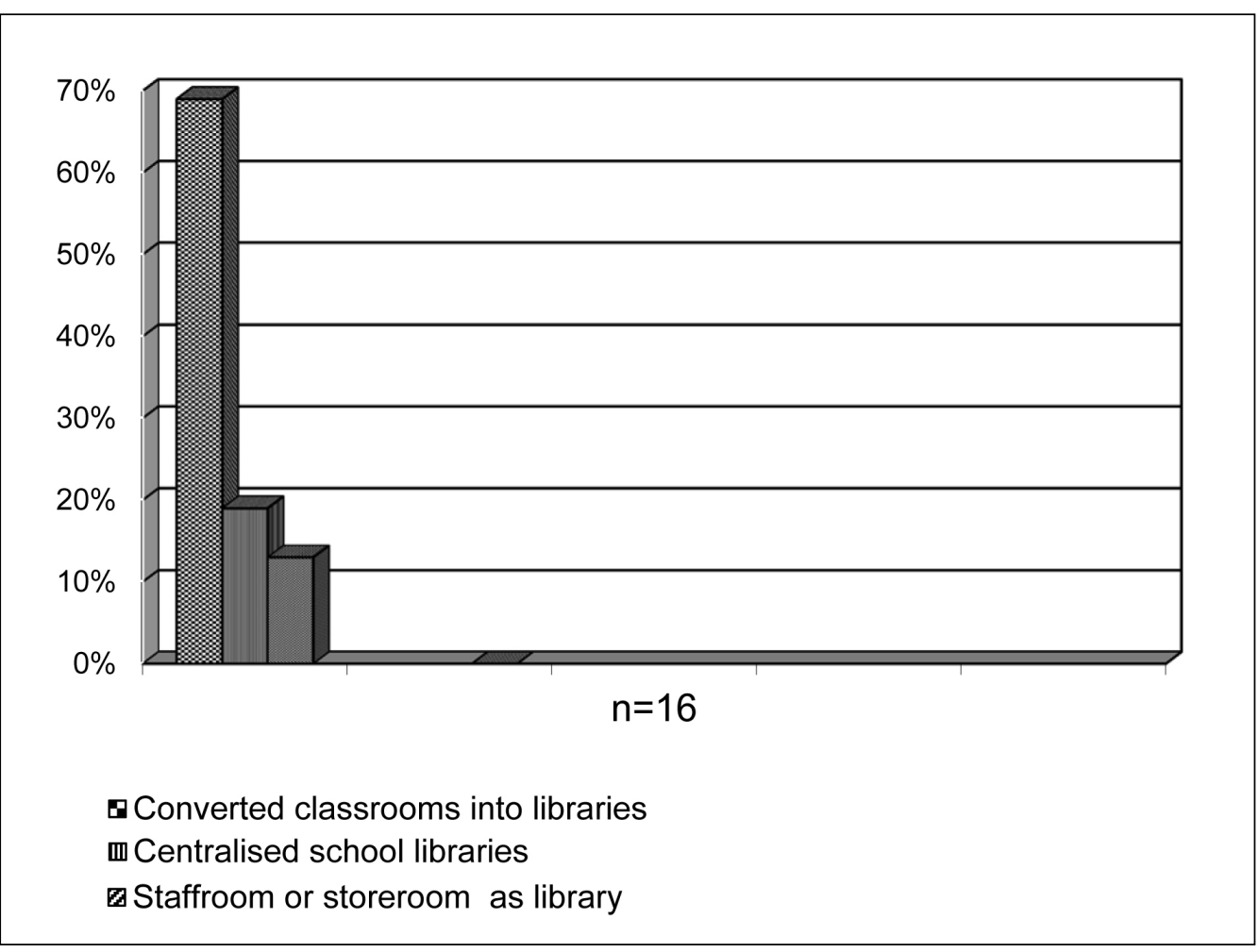

Figure 1: Kinds of school libraries

\subsubsection{Furniture}

Library furniture includes a circulation desk, tables, chairs, shelving, racks, filing drawers and cabinets. Tables and chairs provide seating accommodation. Steel cabinets are required to store the pamphlet collection and shelves are required to house books (SADoBE 2012:41). Respondents were asked to indicate the kinds of furniture available in their school libraries. The results are indicated in Table 2.

Table 2: Furniture in schools

\begin{tabular}{|l|l|l|l|}
\hline Type of furniture & Number of schools & Total & Percentage (\%) \\
\hline Shelves & 13 & 16 & 81.2 \\
\hline Filing cabinets & 12 & 16 & 75.0 \\
\hline Seating chairs & 9 & 16 & 56.2 \\
\hline Tables & 9 & 16 & 56.2 \\
\hline Circulation desks & 4 & 16 & 25.0 \\
\hline Periodical shelving & 1 & 16 & 6.2 \\
\hline
\end{tabular}


Thirteen $(81.2 \%)$ schools have shelving for books and $12(75 \%)$ have filing cabinets; nine $(56.2 \%)$ schools have both chairs and tables; four $(25 \%)$ schools have circulation desks; and one school (6.2\%) has periodical shelving.

\subsubsection{Electricity}

Respondents were asked to indicate whether their schools have electricity. The results show that $13(81.3 \%)$ high schools in Lebopo Circuit are supplied with electricity and three $(18.7 \%)$ are without electricity. These findings are in accordance with results issued by NEIMS (2007:28). It reports that the majority (77\%) of South African schools have electricity, and that in the Limpopo Province as a whole, 85 per cent of schools are connected to Eskom. During data collection, the researcher found one school using a generator to operate a photocopier.

\subsubsection{Audio-visual equipment}

Television monitors, tape recorders, DVD players, video recorders and overhead projectors are examples of audio-visual equipment required to make use of various types of media. Respondents were asked to indicate the types of equipment they have at their schools. Table 3 shows the results.

Table 3: Types of audiovisual equipment in schools

\begin{tabular}{|l|l|l|l|}
\hline Type of audiovisual equipment & Number of schools & Total & Percentage (\%) \\
\hline Television monitors & 9 & 16 & 56.2 \\
\hline Overhead projectors & 4 & 16 & 25.0 \\
\hline Tape recorders & 3 & 16 & 18.7 \\
\hline Video recorders & 3 & 16 & 18.7 \\
\hline
\end{tabular}

Nine (56.2\%) respondents indicated that their schools have television sets; four schools have overhead projectors; and three schools have tape and video recorders.

\subsubsection{Other equipment}

As already implied above, telephones, facsimile (or fax) and photocopying machines and computers are essential equipment in schools. The availability of these facilities is shown in Table 4. 
Table 4: Other equipment in schools

\begin{tabular}{|l|l|l|l|}
\hline Other equipment & Number of schools & Total & Percentage (\%) \\
\hline Photocopy machines & 15 & 16 & 93.7 \\
\hline Computer(s) & 9 & 16 & 56.2 \\
\hline Telephones & 7 & 16 & 43.7 \\
\hline Fax machines & 7 & 16 & 43.7 \\
\hline
\end{tabular}

In Lebopo Circuit, 15 (93.7\%) schools have photocopying machines and nine (50\%) have computers. Schools with computers can be connected to the Internet through a telephone modem or other device using software, such as Internet Explorer. However, only one school indicated that it has access to a computer and this facility is also accessible to the whole community as it was installed by a private company. The researcher observed that the computer was secured with iron bars on the veranda of one classroom so that community members could gain access to it in the afternoon. Other schools use their computers for administration and word processing. Only seven schools have telephones and fax machines.

More than two-thirds (68\%) of the schools in South Africa are without computers for teaching and learning purposes (Rademeyer 2007:11). According to the NEIMS (2007) report, the majority $(82.3 \%$ ) of schools in Limpopo Province are without computers. However, the results of the study show that more high schools in the Lebopo Circuit have computers than is indicated in other reported findings for the whole province.

\subsubsection{Satellite dishes}

Equipment, such as modems, decoders, satellite dishes, receivers and remote controls, are used to pick up signals from satellites to facilitate telecommunications. These telecommunication facilities are necessary so that learners can have access to worldwide information via the Internet and can view television. However, the results show that only three schools have a satellite dish. Respondents were asked if they have facilities to connect to the Internet. Twelve schools (75\%) responded negatively, which means that they do not have the equipment required to enable learners to watch television or to connect to the Internet.

Two other schools have installed satellite dishes, but these satellite dishes are nonoperational because of vandalism and the subsequent theft of decoders and modems. As pointed out by Rademeyer (2007:11), vandalism is a problem in South African schools. This implies that security services are also required to prevent burglary and damage to school property. 


\subsection{COLLECTIONS AND MATERIALS}

All information sources and materials in various formats constitute a library collection. Collections include not only printed, audiovisual and electronic sources but real objects and specimens, or realia (Morris, Gillespie \& Spirt 1992:323; Olën \& Kruger 1995:159160).

\subsubsection{Print materials}

Print materials include fiction (story) books or novels, drama, and poetry books, as well as non-fiction books, newspapers, pamphlets, periodicals, dictionaries and encyclopaedias. The researcher observed that a large number of out-dated textbooks form the largest proportion of the collections. The DoE is responsible for supplying school libraries with encyclopaedias, dictionaries and atlases to serve as core collections. They are essential because many rural schools are not connected to the Internet.

Figure 2 shows the extent to which different types of printed materials are held by schools in the Lebopo Circuit.

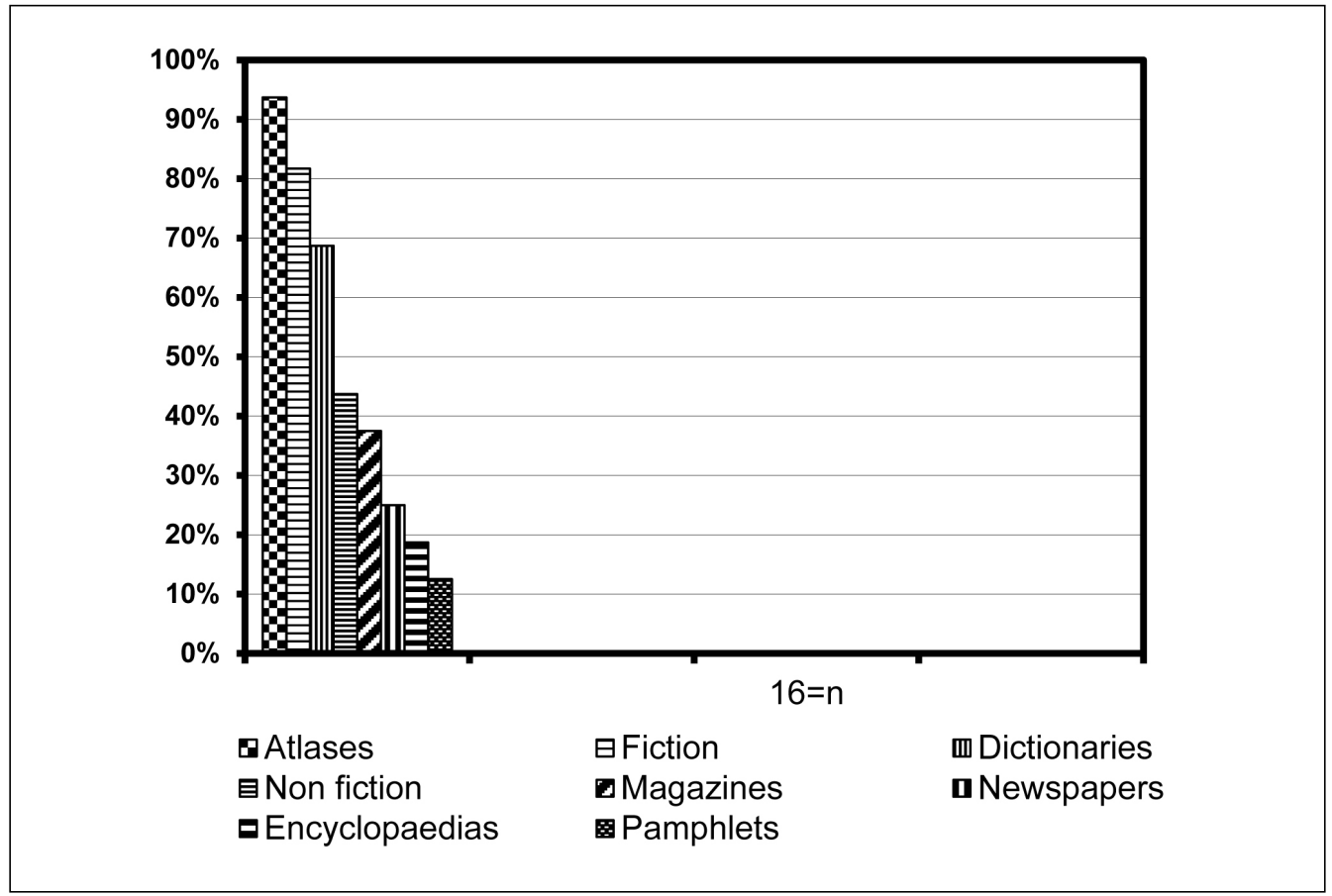

Figure 2: Printed materials in schools

It was found that $15(93.7 \%)$ schools have atlases; 11 (68.7\%) have dictionaries; and only three (18.7\%) own encyclopaedias. Newspapers are acquired by only four schools (25\%). Six schools (37.5\%) have magazines and 13 (81.2\%) have fiction books. 
Although pamphlets are available free of charge, only two (5\%) schools have a pamphlet collection.

\subsubsection{Non-print materials}

Non-print materials include electronic, auditory and audio-visual media as well as realia. Audiotapes and cassettes produce sound and can be used to develop and stimulate the listening and hearing skills of learners. Audiovisual media produce both images and sound. Video cassettes, DVDs and CD-ROM discs stimulate the thinking skills and the imagination of learners. Table 5 shows different types of media held by high schools in Lebopo Circuit.

Table 5: Types of media in schools

\begin{tabular}{|l|l|l|l|}
\hline Types of media & Number of schools & Total & Percentage (\%) \\
\hline Videocassettes & 9 & 16 & 56.2 \\
\hline CD-ROM discs & 6 & 16 & 37.5 \\
\hline Computer software & 5 & 16 & 31.2 \\
\hline DVD discs & 2 & 16 & 12.5 \\
\hline Audiocassettes & 2 & 16 & 12.5 \\
\hline Realia & 4 & 16 & 25 \\
\hline
\end{tabular}

Nine $(56.2 \%)$ respondents indicated that their schools have videocassettes. CD-ROM discs are owned by six (37.5\%) schools, while five (31.2\%) have computer software. Only two (12.5\%) schools have DVD discs and audiocassettes.

Teacher-librarians were asked to indicate whether they keep realia in their library collections. The meaning of the term 'realia' was explained to them personally. Realia are tangible objects, biological specimens (kept in formaldehyde solutions) and natural substances (eg, water and soil) kept in containers. Only four (25\%) teacher-librarians indicated that they keep realia in their resource centres and made them available as teaching aids.

\subsection{BUDGETS AND FUNDS}

To use library funds effectively, a budget should be drawn up indicating all the activities of the school library. The SA DoBE is required to allocate each school with funds for the maintenance of services and the purchasing of resources including library-based resources (Equal Education 2011:9). The National Norms and Standards for School Funding (SA DoE 1998:11) stipulate that 'the state must fund public schools from public revenue on an equitable basis in order to ensure the proper exercise of the rights of learners to education and the redress of past inequalities in educational provision'. 
The document also outlines norms and standards governing procedures to be adopted at provincial levels for resource allocations to schools. It also deals with the procedures to be adopted by provincial education departments in determining resource allocation for schools. The provisioning of learning materials falls within this allocation (SA DoE 1998:11).

Budgets and funds were covered in a second questionnaire intended for the school principals in the Lebopo Circuit. They were asked whether they have a budget for library resources. Figure 3 indicates the results.

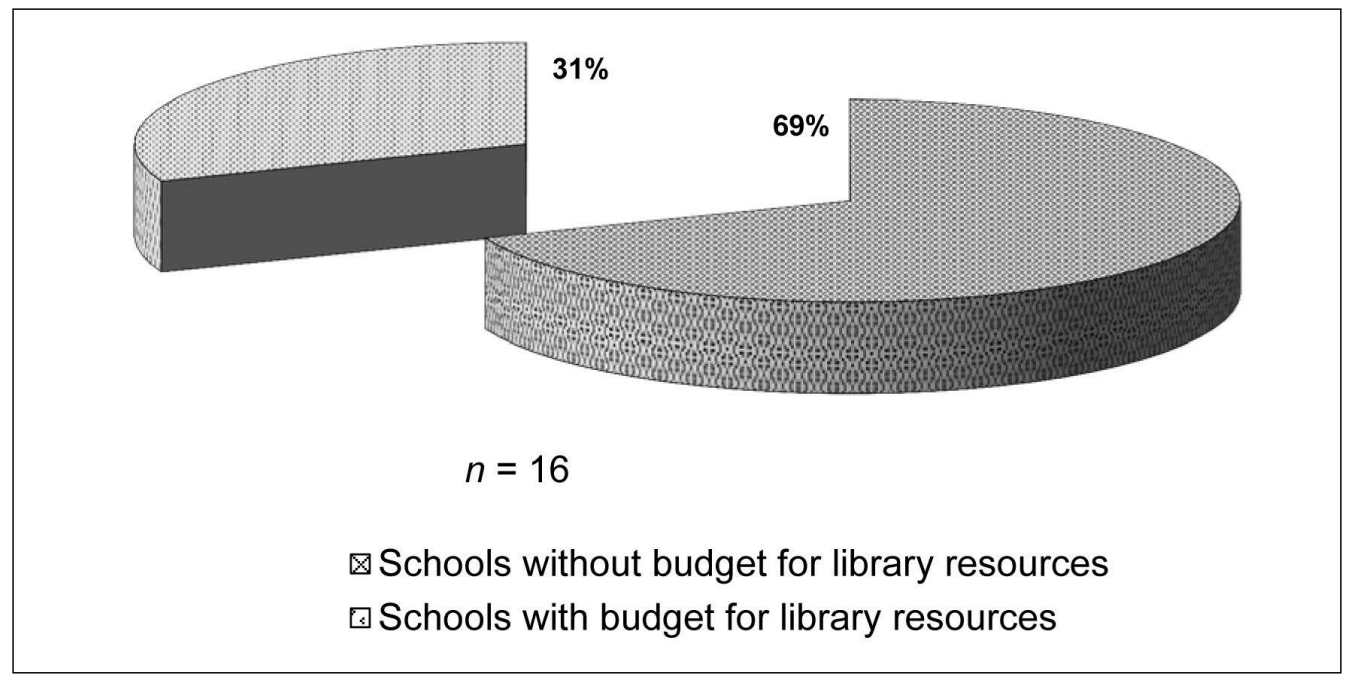

Figure 3: Budget for school library resources

The results indicate that $11(69 \%)$ schools have no budget for library resources. The five schools with a library budget drew it from the Norms and Standards grant and school fees in 2007. Since 2008, the budgets have been drawn from the Norms and Standards grant because all schools in the Lebopo Circuit have been declared 'no fee schools' as they fall in quintile 2. In South Africa, schools are ranked according to poverty levels. Schools in quintile 2 are schools in communities characterised by poor socio-economic conditions. In simple terms, these are schools situated in remote and poor communities. School principals were asked to indicate the percentage of the school budget spent on library resources. Eight (50\%) school principals indicated that they spend none of the school budget on library resources. Only two schools spend 11 per cent and 18 per cent respectively of their school budgets on library resources. School principals were also asked whether sponsors or donors support library improvements. The results indicated that one of the schools with a centralised library receives donations of books from the Polokwane Municipal Library. The majority (93.8\%) of schools do not receive support from sponsors or donors for library resources. 
If school libraries lack funding, resource provisioning is impossible in schools. New books and other library materials will not be bought, and it means that materials in the collection will become worn and outdated and will not be replaced. Essential furniture, facilities and equipment will not be bought either. If schools are so poor that they fall within the 'no fees' norm, they will not be able to build up their own funds to develop library resources as most former Model C schools, which charge school fees, have had to do.

\subsection{SCHOOL LIBRARY COMMITTEES}

The National Guidelines for School Library and Information Services (SA DoBE 2012:22) stipulate that every school in the country should have a library committee. It should be composed of three representatives from the following groups: principal or deputy principal, governing body, teacher-librarian, subject teachers, community library staff, the SRC and parents (Govender 2007). The South African Schools Act (SASA) (Act No. 84 of 1996) gives each school governing body the power to establish library committees to attend to library matters. The school library committee is the body responsible for the smooth running of the school library. It is part of the organisational structure of the school library and carries out certain management activities. School library committees are needed for planning, organising and controlling all activities related to school library matters. They are responsible for drawing up a budget, selecting, ordering, acquiring and weeding library materials and resources.

Teacher-librarians were asked whether their schools have a school library committee, and whether they are members of the school library committee. Figure 4 shows the results.

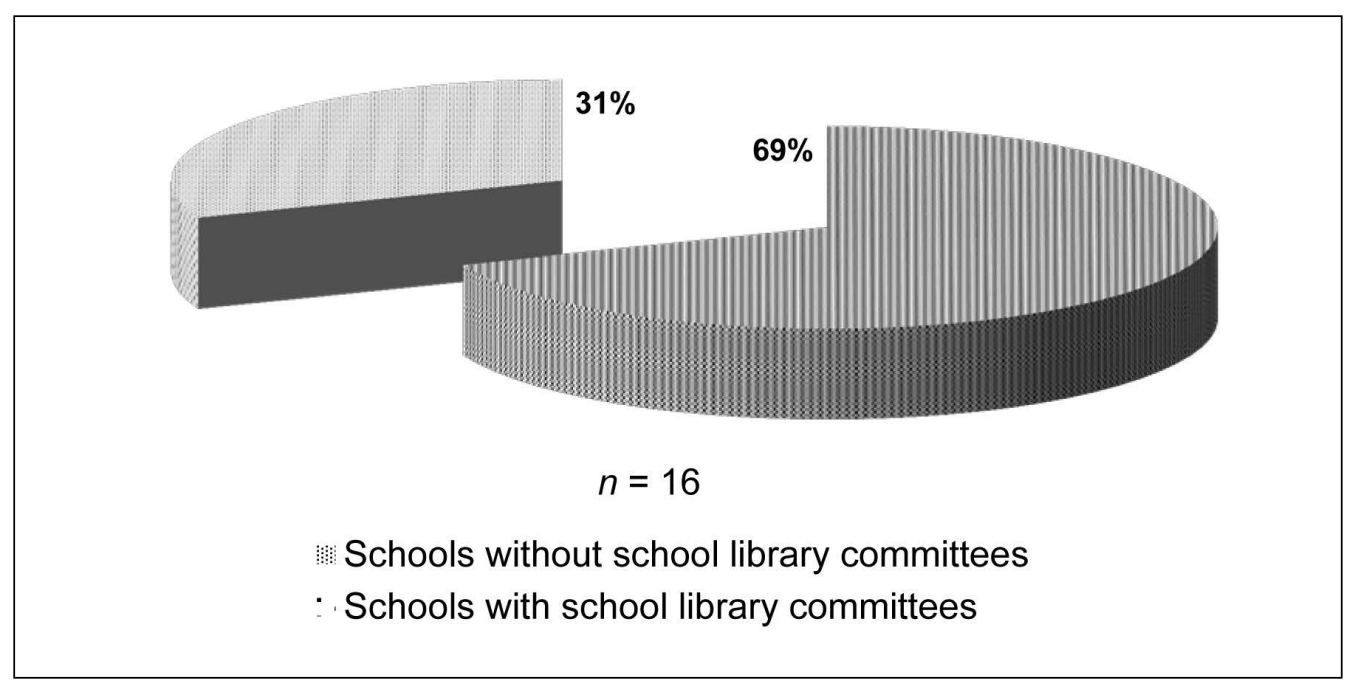

Figure 4: School library committees 
Only five (31\%) respondents indicated that their schools have a school library committee. This result is in agreement with the data collected from the school principals which showed that $11(69 \%)$ schools are without school library committees. As expected, these five respondents indicated that they are members of the committee and that 'other educators' are also members of the committee. None of the respondents identified parents or principals as members of the school library committee.

Teacher-librarians were asked to indicate how many meetings are held by the school library committee per year and to indicate the most important functions or tasks of the school library committee. Five schools indicated that they hold one meeting per year. Three of these schools indicated that the committee is responsible for the issuing and distribution of library materials and two schools indicated that their committees are responsible for the purchasing of library materials and resources. Principals were asked to explain the functions of the school library committee with regard to fund-raising. This was an open question in which respondents could write down their own comments. Some of the principals of the schools with school library committees explained that their committees never venture into fundraising. This situation is unfortunate since 'no fee' schools have no budget to buy library-based resources.

Teacher-librarians were asked to indicate who assists them in running and managing the school library. The options were other educators, learners, parents or guardians and the school library committee. Respondents could also specify any other relevant persons. Nine $(56.2 \%)$ respondents indicated that other educators assist them; five (31.2\%) indicated that their learners assist them; and two (12.5\%) indicated that their school library committee assists them.

\subsection{LIBRARY AND MEDIA USE}

Although learners were not questioned directly about their library use, it was necessary to determine learners' reasons for using library resources and whether it is linked to the demands of the curriculum. This information indicates whether the use of library resources is viewed as necessary for the mastery of aspects covered in the different learning areas. It also indicates whether teacher-librarians are cooperating with teachers in encouraging learners to use resources for assignments, projects and research. The use of library resources is also affected by the opening hours of school libraries or resource centres.

\subsubsection{Library use by learners in various learning areas}

According to the National Curriculum Statement (SA DoE 2007:2), the curriculum consists of 29 subjects. Examples of school subjects in the senior phase are: Languages, History, Life Sciences, Life Orientation, Economics, Mathematics, Physical Sciences, Information Technology and Agricultural Sciences. There are eight learning areas, namely: Technology, Languages, Natural Sciences, Mathematics, Economics and 
Management Sciences, Social Sciences, Arts and Culture, and Life Orientation which form teaching and learning programmes. The Curriculum News (SA DoBE 2011:9-11) announced that the new curriculum (CAPS) would have 28 subjects across all phases.

Teacher-librarians were asked to indicate how frequently learners use library resources for learning purposes in the different learning areas. They were given the options to tick or mark 'often', 'sometimes' and 'never'. Table 6 indicates the results.

Table 6: Use of school library resources in the learning areas or subjects

\begin{tabular}{|l|l|l|l|l|l|l|}
\hline Classrooms converted into school libraries & \multicolumn{7}{|l|}{ Often } & $\%$ & Sometimes & $\%$ & Never & $\%$ \\
\hline Frequency of use in learning areas & 4 & 36.3 & 5 & 45.4 & 1 & 9.0 \\
\hline English & 1 & 9.0 & 6 & 54.5 & 3 & 27.2 \\
\hline Life Sciences & 2 & 18.1 & 4 & 36.3 & 2 & 18.1 \\
\hline History & 1 & 9.0 & 8 & 72.7 & 2 & 18.1 \\
\hline Natural Sciences & 1 & 9.0 & 8 & 72.7 & 2 & 18.1 \\
\hline Arts and Culture & 1 & 9.0 & 9 & 81.8 & 1 & 9.0 \\
\hline Physical Science & 2 & 18.1 & 7 & 63.6 & 2 & 18.1 \\
\hline Geography & 1 & 9.0 & 7 & 63.6 & 3 & 27.2 \\
\hline Agric. Sciences & 1 & 9.0 & 7 & 63.6 & 2 & 18.1 \\
\hline Economics & & & & & & \\
\hline Number of respondents $=11$ & &
\end{tabular}

The data in Table 6 was cross-tabulated with types of library accommodation. The results showed that of the 11 teacher-librarians who run converted classrooms as libraries, most indicated that learners 'often' or 'sometimes' use library resources for learning purposes. These learners often use library resources, in order of frequency, for English, History and Geography. Less frequent use was indicated in respect of Physical Science, Natural Sciences, Arts and Culture, Agricultural Science, Economics and Life Sciences. Of the 11 schools which make use of a converted classroom as a library, only one school indicated that its learners 'never' use resources for learning purposes.

The results in respect of the use of school library resources in staffroom or storeroom libraries and centralised school libraries (a total of five libraries) were disappointing and could not be meaningfully represented in tables. In respect of the three schools which use staffrooms or storerooms as school libraries, one teacher-librarian indicated that learners 'sometimes' use resources and the other two teacher-librarians did not respond at all. Contrary to what would have been expected, in the case of the two schools which have centralised school libraries, one of the teacher-librarians indicated that learners 'sometimes' use the library resources, while the remaining teacher-librarian did not respond. In the case of both types of libraries, only infrequent use of resources in respect of the various learning areas was indicated. Furthermore, insufficient data meant that 
cross-tabulations which could have provided meaningful results in respect of both types of libraries could not be done.

\subsubsection{Library opening hours}

Teacher-librarians were asked to indicate the opening hours of their resource centres or libraries. The libraries of six schools $(37.5 \%)$ are open during breaks; five $(31.2 \%)$ are open during class periods; and three (18.7\%) can be used during free periods. In the two remaining schools, learners use library resources before and after school.

\subsection{RESPONDENTS' VIEWS ON THE STATE OF LIBRARY RESOURCES IN SCHOOLS}

\subsubsection{Teacher-librarians}

Respondents were asked to write their comments and opinions about the state of the library resources in their schools. Teacher-librarians at nine $(56.2 \%)$ schools indicated that a library building, furniture, computers, funds and access to the Internet are needed to support a fully-fledged school library service. Six (37.5\%) teacher-librarians indicated that new and recent books, dictionaries, encyclopaedias, newspapers and magazines are needed. One respondent did not comment pointing out that as her school lacked a centralised library building she could not comment on library resources.

\subsubsection{School principals}

School principals were asked to give their opinions on funding for school library resources. Ten principals $(62.5 \%)$ indicated that more funding is needed to buy library resources and materials; four (25\%) did not comment; and two (12.5\%) indicated that sponsors and donors are needed for library improvements at schools.

\section{DISCUSSION AND SUMMARY OF FINDINGS}

\subsection{STAFF QUALIFICATIONS}

Although teacher-librarians should have both teaching and Library and Information Science qualifications, the majority of teacher-librarians in the Lebopo Circuit do not have professional qualifications. This result could imply that there is a shortage of qualified teacher-librarians in the Lebopo Circuit and that it could also apply to other circuits, other districts and to the Limpopo Province as a whole.

This impacts negatively on the organisation and retrieval of information, as teacherlibrarians without qualifications in librarianship lack the professional skills to enable 
them to catalogue and classify the materials in the collection. That is why the collections in schools in the Lebopo Circuit are unsystematic and disorganised making it difficult to access and retrieve information and information sources.

\subsection{ACCOMMODATION}

Although space is essential to accommodate and house all library materials, equipment and hardware, only two schools had fully-fledged school libraries. In 11 schools, converted classrooms are used as libraries. However, some of these libraries function as storerooms rather than as school library collections. This result is in agreement with previous findings reported in the subject literature that there is a shortage of functional school libraries in Limpopo as a whole (NEIMS 2007; SA DAC \& NCLIS 2009:42).

\subsection{FURNITURE, OTHER EQUIPMENT AND ELECTRICITY}

The majority of the schools in Lebopo Circuit have shelves and filing cabinets and over half have tables and chairs. Study carrels, display shelves, periodical shelving and circulation desks are needed in most of the schools. Most of the schools have photocopying equipment but some schools were still without computers, telephones and fax machines. The majority of the schools do not have satellite dishes to view television or the equipment required to connect to the Internet. Over half of the schools own television sets and some own overhead projectors, tape recorders and video recorders. The majority of the schools are connected to Eskom and one school has installed a generator. This is advantageous, because electronic equipment could be used even if there are power-cuts. Clearly, teaching and learning is greatly affected by a lack of electricity. For instance, educators cannot photocopy articles from newspapers and periodicals, or copy diagrams and drawings from books to make teaching and learning interesting and stimulating.

\subsection{COLLECTIONS AND MATERIALS}

Few of the schools have a balanced collection that will meet the curricular needs of teachers and learners. Atlases are generally available in most schools. The majority own works of fiction and dictionaries. Newspapers, encyclopaedias and pamphlets form part of the collections of only a few schools. More than half of the schools have video cassettes, while there is generally a shortage of CD-ROMs, computer software, DVD discs and audiocassettes.

\subsection{BUDGET AND FUNDS}

Although a budget should be drawn up so that funds can be used appropriately, 11 schools (two-thirds) do not have a budget for school library resources and materials. Only two of the schools allocate a small percentage of each of their school budgets to 
acquiring library resources. The majority of the school principals indicated that more funding is essential for schools to buy library resources, but only two school principals felt that sponsors and donors are needed for library improvements.

Only one school received a donation of books from the Polokwane Municipal Library. Most of the schools have neither sponsors nor donors. Only five schools in the Lebopo Circuit have school library committees. This is one of the reasons why libraries are nonfunctional.

\subsection{LIBRARY AND MEDIA USE}

Two schools with fully-fledged school libraries are excluded from the discussion of findings in respect of learners' library use. Although their collections are organised and systematic and information is easily accessible, they failed to respond adequately to questions on the questionnaire. Furthermore, it is assumed that these libraries are an integral part of teaching and learning in these schools, and learners can use the libraries as they wish. This may not be the case in schools which do not have functional libraries. Therefore, library use for learning purposes in the last-mentioned schools is particularly significant if it occurs.

Of the 11 schools which make use of a converted classroom as a library, only one school indicated that its learners 'never' use resources for learning purposes. Library resources are used more often for English, History and Geography than for other learning areas. School learners would probably use collections more often for learning purposes if they received guidance and information skills instruction from professionally qualified teacher-librarians. As the majority of teacher-librarians in the Lebopo Circuit are not professionally qualified, the conclusion could be drawn that it would be difficult for them to encourage learners to use school libraries because they probably lack information skills themselves.

In the remaining schools, library resources are housed in a storeroom or staffroom with inadequate seating space for learners to make use of resources. The use of library resources is also influenced by the opening hours of the facility. Most school libraries are open during breaks, class periods, or during free periods, but only two are open before and after school.

\section{RECOMMENDATIONS}

Based on the above-mentioned findings of the small study conducted in high schools in the Lebopo Circuit, Capricorn District, certain recommendations can be made that could also be applicable to rural schools in Limpopo Province as a whole. 


\subsection{STAFF}

\subsubsection{Staff qualifications}

There is a shortage of qualified teacher-librarians in the Lebopo Circuit mainly because there is no post provisioning made for the appointment of qualified teacher-librarians in public schools. It is unfortunate that schools in economically deprived areas in Limpopo Province cannot employ qualified professional teacher-librarians to manage school libraries since individual 'no fee' schools do not generate their own funds to enable them to do so.

\subsubsection{Library use}

Subject educators, in collaboration with teacher-librarians, should give learners assignments and research projects, so that they can learn to use various library media to find information.

\subsubsection{Opening hours}

School libraries should also be open during non-school hours to give learners and educators enough time to use resources and to search for information from various sources at their own pace.

\subsection{FACILITIES}

\subsubsection{Accommodation}

Although the ideal is for each school in Limpopo Province to have a fully-fledged school library building, the governing authorities should also consider other methods for the provisioning of library resources. Since there is a shortage of operational school libraries in Lebopo Circuit, the Limpopo DoBE should consider building cluster libraries which share their resources. It should cooperate with community or public libraries in the use of mobile libraries to solve the problem of a lack of accommodation.

\subsubsection{Furniture}

The Limpopo DoBE should ensure that school libraries are suitably furnished to provide seating for learners and educators and that sufficient shelving is provided to house books and other materials.

\subsubsection{Electricity}

Generators and solar panels (although expensive) could serve as alternative sources of electrical energy in schools without electricity. The Limpopo DoBE should allocate more funds for schools to install them. As Eskom experiences problems with the supply 
of power, generators and solar panels could be used as back-ups in schools if funds permit.

\subsubsection{Equipment}

The Limpopo DoBE should compile an inventory of the ICT equipment in schools. Telephones, fax machines, computers and photocopiers should be supplied to schools accordingly. This equipment is essential since an information service cannot function effectively without a means of communication with other libraries to conduct interlibrary loans or to contact book suppliers.

\subsubsection{Satellite dishes and Internet access}

The Limpopo DoBE should ensure that all schools have satellite dishes to view television programmes for learning especially in remote areas where reception is poor. Computers, modems or other devices and relevant software packages are required to connect to the Internet. This would ensure that learners can acquire the necessary information skills to gain access to information for self-study from online databases.

\subsubsection{Security at schools}

As some schools are vandalised and school property is stolen, all public schools should have security measures in place (DoBE 2012:18). Apart from appointing security guards, tight supervision in respect of moveable property should be put in place by the schools themselves. Library equipment should be kept under lock and key. Loan procedures and book circulation should be monitored closely to ensure that borrowed materials are returned to the school.

\subsection{COLLECTIONS AND MATERIALS}

\subsubsection{Print materials}

The SA DoBE should provide schools with a variety of library materials as laid down in the National Guidelines for School Library and Information Services (SA DoBE 2012:28). The print collection should include books covering the various learning areas, periodicals, newspapers, atlases, dictionaries and encyclopaedias to provide a core collection for each school (Dubazana \& Hoskins 2011:121). Pamphlets and brochures, newspapers and magazine cuttings could be collected to form a vertical file collection on topics covered in the curriculum. This could be done by teacher-librarians themselves with the assistance of learners as library monitors at no cost to the school. 


\subsubsection{Non-print materials}

The Limpopo DoBE should compile an audit of the audiovisual and electronic media owned by schools, and supplement the school library collection accordingly. Audiovisual and electronic media stimulate learners' imagination because different senses are involved in its use. These media supplement printed materials and are particularly valuable for rural learners.

Realia can be collected and kept in the school library in containers or display cabinets. Samples of different types of soil to teach soil structure and texture can be collected for the Agricultural Sciences. Botanical and biological specimens facilitate learning in the Life and Natural Sciences.

\subsection{BUDGETS AND FUNDING}

The Limpopo DoBE should provide more funding to purchase equipment and materials for school libraries. It should ensure that a certain percentage of the Norms and Standards grant allocated to schools is spent on the provisioning of library and information resources.

However, it may be some time before the recommendations mentioned here can be put into practice since the Limpopo DoBE is currently under administration because of irregular expenditure and cash flow problems. As a result the Department cannot meet its financial commitments in respect of resource provisioning in schools. Textbooks were not ordered in time because of the possible mismanagement of funds. According to Davis (2012:5), expertise and knowledge are essential when officials of the Department are drawing up a budget and they must ensure that it is followed to the letter to avoid irregular expenditure leading to the mismanagement of funds in future.

\subsection{SCHOOL LIBRARY COMMITTEES}

School library committees should be constituted in all schools to manage school library resources as stipulated in the National Guidelines for School Library and Information Services (SA DoBE 2012:22). This includes assisting in drawing up budgets for school library resources. School library committees should lobby private companies to sponsor their school libraries or to donate library resources and other materials, and school principals should support them. These committees could approach private sector companies and universities to adopt school libraries. School library committees should also consider alternative sources of funding in the form of fundraising events in order to build up funds for the acquisition of library resources. However, it would be difficult for 'no fees' rural schools to raise funds. 


\subsection{SCHOOL LIBRARY POLICY}

The Limpopo DoBE (2012) has recently developed a discussion document on school library policy. However, it has not yet been finalised because relevant input is still awaited from school governing bodies, principals and teacher-librarians. Such a policy could serve as a guideline pertaining to school library matters (Du Toit 2008:49). It is the responsibility of the Department to ensure that it is implemented.

\section{CONCLUSION}

Although the findings of the current small study cannot be generalised to apply to a wider population because the investigation covered a very low percentage of high schools in Limpopo Province, the results could imply that there is a shortage of library resources in rural schools in Limpopo as a whole. It is clear that more funds are needed to develop school libraries since only two high schools in the Lebopo Circuit have functional libraries. The collections in converted classrooms serving as libraries are neither catalogued nor classified, making information retrieval very difficult. Only a small percentage of teacher-librarians have librarianship qualifications. This situation has impeded the implementation of resource-based learning in rural schools and may impede the implementation of the new curriculum in future.

Finally, some doubts are raised about the capacity of the Limpopo DoBE to address the challenge of equipping rural schools with library facilities and the necessary resources to meet the requirements of the school curriculum.

\section{REFERENCES}

Australian School Library and Information Association. 2004. Policy statement - teacherlibrarians in Australia. http://www.asla.org.au/policy/p_tlaust.htm (Accessed 30 April 2007).

Bothma, T, Cosijn, E, Fourie, I \& Penzhorn, C. 2008. Navigating information literacy: your information society survival toolkit. Cape Town: Pearson Prentice Hall.

Calvert, PJ. 2001. Conference reports, in Inspiring connections, learning, libraries and literacy. Proceedings of the 30th Annual Conference of the International Association of School Librarianship and the 5th International Forum on Research in School Librarianship. Wellington, New Zealand: Victoria University: 1-3.

DAC see South African Department of Art and Culture.

Davis, G. 2012. Long list of ills at various departments. The Star, 20 January.

Dewe, M. 1995. Planning and designing libraries for children and young people. 2nd ed. London: Library Association.

DSAC see South African Department of Sport, Arts and Culture. 
Dubazana, K \& Hoskins, R. 2011. Promoting equitable access to school libraries in KwaZuluNatal: the role of the Education Library Information and Technology Services (ELITS). Innovation 42:114-131.

Du Toit, M. 2008. KwaZulu-Natal school library policy and its feasibility for implementation in the province. PhD thesis, University of KwaZulu-Natal, Pietermaritzburg.

Equal Education. 2011. We can't afford not to: costing the provision offunctional school libraries in South African public schools. Elonwabeni: Equal Education.

Fourie, JA \& Gericke, EM. 2009. A theoretical model for the provision of educational and career guidance and information services for high school learners in public libraries. Mousaion 27(1):1-23.

Furlonger, D. 2004. Election promises mean little to these children: life goes on as usual for under-resourced rural schools. Financial Mail 176(3):67.

Govender, R. 2007. The role of the school library committee in governance: case studies of three public schools in KwaZulu-Natal. MEd dissertation, University of KwaZulu-Natal, Durban.

Government of Ethiopia. 2005. Education for Rural People (ERP): Ministerial Seminar on Education for Rural People in Africa: Policy Lessons, Options and Priorities, 7-9 September, Addis Ababa, Ethiopia: 1-9.

Hart, G. 2012. Searching for new library models: two South African case studies of services to youth, in Libraries for young people: breaking through barriers. Pre-conference - World Library and Information Congress, IFLA Section, Libraries for Children and Young Adults, 9-10 August, Joensuu, Finland: 1-11.

Hart, G. 2013. How school libraries improve literacy: some evidence from the trenches. Mousaion 31(1):47-60.

Hart, G \& Zinn, S. 2007. The conundrum of schools in South Africa. Cape Town: University of Cape Town. http://www.sapartners.org/documents/schoollibraries.pdf (Accessed 30 April 2007).

Hoskins, R. 2006. The potential of school libraries for promoting less polarized social relations in the post-apartheid era. Alternation 13(2):236-251.

Kruger, JA. 1998. The role of the school library in Curriculum 2005. Mousaion 16(1):2-14.

Limpopo Department of Education. 2007. Annual survey, update master. Polokwane: DoE.

Limpopo Department of Basic Education. 2012. School library policy: the discussion document. Polokwane: DoBE.

Limpopo Department of Sport, Arts and Culture. 2009. 2009/10 draft plan. Polokwane: DSAC.

Machet, MP \& Olën, SII. 1997. Literacy environment of pupils in urban primary schools. South African Journal of Library and Information Science 65(2):77-84.

Machet, MP \& Pretorius, EJ. 2008. The impact of storybook reading on emergent literacy: evidence from poor rural areas in KwaZulu-Natal, South Africa. Mousaion Special Issue: 261-289.

Magara, E \& Nyumba, JB. 2004. Towards a school library development policy for Uganda. Library Review 53(6):313-322.

Mahwasane, NP. 2008. Provision of library services to disadvantaged children in rural areas of the Limpopo Province. MInf dissertation, University of South Africa, Pretoria. 
Mnkeni, N. 2007. The effectiveness of teacher-librarians in primary school: the experience of the Melani school libraries in the Eastern Cape. MBibl dissertation, University of Cape Town, Cape Town.

Mojapelo, MS. 2008. Library and information resources in the rural schools of Limpopo Province: a pilot study. MInf dissertation, University of South Africa, Pretoria.

Morris, BJ, Gillespie, JT \& Spirt, DL. 1992. Administering the school library media center. 3rd ed. New Providence, NJ: Bowker.

Mutula, SM. 2004. Making Botswana an information society: current developments. The Electronic Library 2(22):144-153.

Naidoo, V. 1997. The role of information skills, curriculum resource material and education library and information services in Curriculum 2005. Mousaion 15(2):3-9.

NCLIS see National Council for Library and Information Services.

NEIMS see National Education Infrastructure Management System.

National Education Infrastructure Management System. 2007. National assessment report (public ordinary schools). Contract EDO30. www.education.gov.za/LinkClick.aspx?fileticket... tabid=358\&mid (Accessed 30 April 2007).

Okiy, RB. 2003. Information for rural development: challenge for Nigerian rural public libraries. Library Review 52(3):126-131.

Olën, SII \& Kruger, JA. 1995. The role of the school media centre. Mousaion 13(1/2):148-169.

Rademeyer, A. 2007. Swak infrastruktuur raak onderriggehalte: net 7\% van skole in SA het biblioteke. Beeld, 14 September: 11.

Saitis, C \& Saiti, A. 2004. School libraries in Greece: a comparative study of public primary schools in rural and urban areas. Library and Information Science Research 26(2):201-220.

Smit, PJ \& Cronje, GJ de J (eds). 1997. Management principles: a contemporary edition for Africa. 2nd ed. Kenwyn: Juta.

South Africa Department of Arts and Culture \& National Council for Library and Information Services. 2009. Library and Information Services Transformation Charter. Pretoria: DAC.

South Africa Department of Basic Education. 2011. Curriculum news: improving the quality of learning and teaching: strengthening curriculum implementation from 2010 and beyond. Pretoria: DoBE.

South Africa Department of Basic Education. 2012. National guidelines for school library and information services. Pretoria: DoBE.

South Africa Department of Education. 1996. South African Schools Act of 1996 (SASA), Act No. 84 of 1996. Pretoria: DoE.

South Africa Department of Education. 1998. National norms and standards for school funding. Pretoria: DoE.

South Africa Department of Education. 2003. National curriculum statement, grades 10-12: computer applications technology. Pretoria: DoE.

South Africa Department of Education. 2007. National curriculum statement grades $10-12$ (general). Learning programme guidelines: Life Sciences. Pretoria: DoE. 
South Africa Department of Sport, Arts and Culture \& National Council for Library and Information Services. 2009. Library and Information Services Transformation Charter: the draft. Pretoria: DSAC.

Uhegbu, AN. 2001. Deterrents to information service for community development. Library Review 50(5):237-242.

Van Teijlingen, ER \& Hundley, V. 2001. The importance of pilot studies. Social Research Update 35:1-9.

Wijetunge, P. 2000. The role of public libraries in the expansion of literacy and lifelong learning in Sri Lanka. New Library World 101(3):104-111.

Wong, LL. 1999. Adopt a rural school library: Chiao urges aid to poor regions of China. Library of Congress Information Bulletin 58(6):142. 